\title{
A citation analysis of Catalan literary studies (1974-2003): towards a bibliometrics of humanities studies in minority languages ${ }^{1}$
}

Jordi Ardanuy². Cristóbal Urbano

Departament de Biblioteconomia i Documentació. Universitat de Barcelona. Edifici UB-Sants, C/ Melcior de Palau, 140, 08014 Barcelona, Catalonia (SPAIN).

Lluís Quintana

Departament de Filologia Catalana. Universitat Autònoma de Barcelona. Edifici B Campus de la UAB, 08193 Bellaterra (Cerdanyola del Vallès), Catalonia (SPAIN)

\begin{abstract}
A citation analysis was carried out on the most important research journals in the field of Catalan literature between 1974 and 2003. The indicators and qualitative parameters obtained show the value of performing citation analysis in cultural and linguistic areas that are poorly covered by the A\&HCI. Catalan literature shows a similar pattern to that of humanities in general, but it could still be in a stage of consolidation because too little work has as yet been published.
\end{abstract}

\section{Introduction}

Few bibliometric studies based on citation analysis have been made in the field of the humanities in comparison with other disciplines [STONE, 1982; HeruBEL, BuCHANAN, 1994; THOMPSON 2002]. The main reason for this is assumed to be the lack of exhaustive tools in humanities equivalent to the SCI, and to a lesser extent the SSCI. This situation is due to the traditional importance of writing monographs [WATSONBOONE, 1994; LINDHOLM-ROMANTSCHUK, WARNER, 1996] and the use of vernacular languages other than English that are not well represented in the A\&HCI [NEDERHOF ET AL., 1989; CULLARS 1990; URBANO ET AL., 2005].

The specific bibliometric studies of literature carried out so far have covered mainly languages with a large number of speakers: British and/or American literature in English [GleAves, 1961; HeINZKILl, 1980; STERN, 1983; Cullars, 1985; BudD, 1986; ThOMPSON, 2002]; German literature [Cullars, 1989]; French literature [Cullars, 1989]; Spanish literature [Cullars, 1990] and Italian literature [CullaRS, 1990]. However, to the authors' knowledge no studies have dealt with literatures corresponding to languages with fewer potential users that have to compete in their geographic area with more widespread languages. This is the case of Catalan.

\footnotetext{
${ }^{1}$ Post-print.

Published source: Scientometrics Volume 81, Number 2, 347-366,

DOI: $10.1007 / \mathrm{s} 11192-008-2143-3$

Accessible at http://www.springerlink.com/content/mn46738315588302/fulltext.pdf

2 jordi_ardanuy@ub.edu
} 
The literature in Catalan is that of Catalonia and other territories that surround it (the Valencian Community and the Balearic Islands in Spain; Andorra where it is the only official language; the Roussillon, in France, and a few smaller places). The set of Catalan-speaking territories is habitually known as Països Catalans. They cover a total area of $68.000 \mathrm{sq} \mathrm{km}$ inhabited by 13.5 million persons, of whom 9 million can speak the language and 11 million can understand it.

There are currently five television channels that are exclusively in Catalan and three more that are bilingual (Catalan and Spanish), in addition to many local stations that broadcast mainly in Catalan. There are several news and general interest magazines in Catalan, three daily newspapers with an average circulation of 180,000, and a wide variety of local and regional publications. There are 6 major radio stations broadcasting in Catalan and a large number of local ones broadcasting totally or mainly in Catalan.

The present bibliometric study of scientific production on Catalan literature is intended as a contribution to the little explored area of national literatures. In particular, it contributes to knowledge of the dynamics of a discipline that is lacking in studies of all types. Research on Catalan literature has been subject to the highly negative effect of the political and social events that occurred in Spain in the mid-20th century. It is only recently, with the institutionalisation of Catalan philology chairs in Spanish universities, that this field of study has begun to be professionalised, and the significant stock of published knowledge has been analysed in general reports [MOLAS, 2001; DURAN, 2001; DURAN, 2004].

\section{Methodology}

Due to the absence of articles on Catalan literature in the citation databases published by Thomson Scientific, an ad hoc database of citations was drawn up by manually extracting 6,109 bibliographic references. The selection of the core of serial publications from which to perform the extraction was based on a preliminary study aimed at determining the most important publications in the discipline: Caplletra, Els Marges, Estudis Romànics, Randa, and Serra d'Or [URBANO ET AL., 2004]. The extraction process showed that these publications had been well selected.

The time period was set at 30 years, sufficiently long to study variations in the dynamics of the discipline, but within the possibilities of the resources available. The appearance of Els Marges in 1974 and Randa the following year marked the recovery of research journals on Catalan literature. Caplletra did not appear until 1986, whereas Serra d'or, a more general publication, had been published since 1959. The end date of 
2003 ensured the complete availability of the journals, in view of the slow rate of publication of some of the publications reviewed ${ }^{3}$.

The citations were extracted by introducing in the database all the citations that appeared in each document surveyed, one by one. In cases of repetition they were introduced only once, and they were taken from the final references or footnotes according to the format used by each publication.

The articles surveyed systematically were all dedicated totally, or largely, to the study of Catalan literature, i.e. literary criticism and analysis. Reviews of books, stage productions and literary prizes were specifically excluded. Though many of the citations were to primary sources, mainly literary works, only citations of non-literary sources were considered, i.e. secondary sources such as theoretical and methodological studies and texts on literature, history, philosophy, linguistics and other disciplines that are auxiliary to Catalan literature. Citations of primary sources, i.e. works that were the object of study by the researchers, such as poems, novels and other narrative works, plays, etc. were not considered, regardless of their format or the medium in which they were published ${ }^{4}$.

All the citations gathered, whether citing or cited, were introduced in a single relational database. A relation was established between the cited and citing documents, indicating whether it was a self-citation, i.e., a citation of an author's own work. Complementary tables were also used to ensure a good control of authorities.

For each register, essential bibliographic data were noted, such as the document title and the series or part, if applicable; the number of authors; the authors' names; the date of publication; the language in which the documents were written; the language of the original document if it was a translation; and the format. These are the aspects widely gathered and analysed in bibliometric studies of humanities [THOMPSON, 2002; AL, SAHINER, TONTA, 2006; NEDERHOF, 2006], which allows comparisons to be made.

In parallel the cited documents were classified according to thematic features such as literary genres, the period of study, the geographic area of study, the literary authors analysed and their artistic works. Thematic studies, though not so common, have precedents in humanities in works such as those of HeINZKILl [1980] and CuLlars, [1989; 1990; 1996; 1998]. To do this the title of the document cited was used, in addition to other bibliographic data such as the context of the citation. In cases of ambiguity, the document was identified in bibliographic databases in order to increase the information, and in a few cases it was consulted physically. The statistical analysis was performed using a spreadsheet, SPSS, UNICET and Pajek.

\footnotetext{
${ }^{3}$ It must be noted that these works formed part of a wider research project that required homogeneous data periods. The information forms part of the doctoral thesis of Ardanuy [2008], available online at: $<$ www.tesisenxarxa.net/TESIS_UB/AVAILABLE/TDX-0226108-124023//JAB_TESI.pdf>, accessed on 20 March 2008.

${ }^{4}$ However, an estimation of the presence of these citations was based on the percentage of primary and secondary citations of the journal Serra d'Or between the 1994 and 2003. The result was that $41.3 \%$ of sources were primary and therefore $58.7 \%$ secondary. This is an intermediate value with regard to those obtained in the studies of literature by BUDD [1986], CULLARS [1989; 1990] and THOMPSON [2002].
} 


\section{Results and discussion}

\section{Disciplinary area and document types}

Of the total of 6,109 citations corresponding to secondary sources gathered, 4,096 (67\%) were identified strictly as corresponding to Catalan literature, whereas 2,013 (33\%) were from auxiliary or complementary disciplines for scholars of Catalan literature, such as language, history, philosophy and plastic arts. This value is higher than the 25\% found by CULLARS [1998] in the case of monographs on philosophy.

Whenever possible, the main subject matter dealt with by these citations of auxiliary disciplines was systematically gathered. The predominant subject was history, which appeared in $25.9 \%$ of the cases, followed by literary theory and comparative literature, which appeared in $20.3 \%$ of the cases. Of the citations, $18.8 \%$ corresponded to studies of other literatures, whereas $11.1 \%$ dealt with language, mainly Catalan. Further details of the other literatures are shown in Table 1. Over a third of the articles corresponded to Spanish literature, followed at a great distance by French literature.

The documents cited showed a clear predominance of work published in book format (monographs, published books, compilations and forewords to literary works, as shown in Table 2). The number of book citations was higher for all documents cited than for those specifically referring to literature. This is easily explained by the fact that when scientists use sources from complementary disciplines, such as history and philosophy, monographs are more familiar and accessible to them than articles or other types of document.

These results are in agreement with those of most studies in areas of the humanities, which also show a predominance of monographs [ARDANUY 2008]. Table 3 shows the results obtained in previous works on philology, in increasing order of importance of the serial publications. Though in many of these cases the serial publications include all the journals, conferences and other periodical materials, we observe that the $32.42 \%$ obtained for journals on Catalan literature is comparatively very high. This shows that in view of their general impact these publications are fundamental in the discipline.

Conference proceedings represented $4.83 \%$ of the total, with a value that doubled during the study period. The periodical press showed a very similar value (4.74\%), but with a downward tendency during the study period.

Until 2003 formats other than paper were rare, with 99.79\% of the citations analysed being in paper format. Apart from 8 references to speeches or interviews that were apparently not published and were therefore not available in any format, 4 references were to websites (http protocol) and one to a database in a tangible format (CD). These results do not differ from those of ELLIS and OLDMAN [2005] and SHAW [2002] on the use of information technologies among British researchers of English literature. These authors conclude that though the use of technological media related to computers have had an impact on several aspects of teaching, communication and source consultation, most academics are reluctant to publish in electronic media. 
Though the introduction of electronic journals should change this situation, the change will be gradual. Of the most cited journals in Catalan literary studies according to the present work (Table 6), only Estudis Romànics and Llengua \& literatura, occupying ninth and eleventh place in the ranking, have online versions.

\section{Language}

With respect to the language used in the documents cited, we must differentiate again between those referring to Catalan literature and those belonging to auxiliary or complementary disciplines. In the former, there was a total predominance of Catalan, at 86.1\% of the references, followed at a great distance by Spanish (9.7\%), English (1.46\%), French (1.42\%) and Italian (0.9\%). There are therefore very few publications in English on Catalan literature, with a percentage of references very similar to French. Italian was even further behind, and other languages were very rare.

The situation was very different for references that were not strictly to Catalan literature but to literary theory and comparative literature, linguistics and other artistic, philosophical or religious subjects. Here the dominant language was Spanish at 37.2\% of the references, followed closely by Catalan at $32.5 \%$. In view of the overwhelming presence of Catalan in the citations on Catalan literature, and the fact that they represent $68.5 \%$ of all citations, this predominance of Spanish in the auxiliary disciplines is probably due to the fact that it is the preferred language when there are no suitable equivalents in Catalan. This is because most of the researchers in Catalan literature that are cited are Spanish. A similar situation is found in contexts that are linguistically similar to that of Catalonia, such as Holland and Flanders [NEDERHOF ET AL., 1989; Nederhof, ERlings, 1993] and Malaysia [ZAinAB, GoI, 1997], where the lack of documents in the native languages is made up for by using sources in English. As a third of the works cited are not documents in Catalan, this seems to indicate that there is a major lack of scholarly work in Catalan in the field of the humanities.

\section{Year of publication and obsolescence}

With regard to the specific references on Catalan literature, the period covered was very long, even for secondary sources: from 1749 to 2003. Figure 1 shows the chronological evolution since 1869. The periods with most citations are 1984-1988 and 1989-1993. An interesting aspect is the variation of citations from one period to another. The decline in the last two periods is typical of the lack of immediacy in the use of publications. On the other hand, though they may be related to the political evolution of the Catalan-speaking countries, the variations between citations of texts from the 19th century and the first third of the 20th century are of little importance because they are small in number. The major fall in the period 1939-1943 was undoubtedly related to the Spanish Civil War (1936-1939). From the period 1954-1958 to 1959-1963 there was a $200 \%$ increase in the number of citations, from 68 to 204. This increase is very 
significant because it is related chronologically to the appearance of Serra d'Or the first cultural serial publication in Catalan since the Civil War, published by the Abbey of Montserrat thanks to the agreements between the Spanish government and the Vatican. Serra d'Or was a reference for all types of work on Catalan language and literature in the most difficult periods of the Franco regime.

With regard to synchronous obsolescence, the half life was 11 for all the documents and 9 for the ones referring strictly to Catalan literature. The average age of the citations was 18.7 years for all the documents and 16.2 years for those of Catalan literature, and the Price indexes corresponding to the percentages of references to literature published in the last five years were 31.5 and 35\%, respectively. The general level of obsolescence was low compared with the typical values of scientific disciplines such as genetics, physics and information technology, which have a half life of 3 to 6 years [STINSON, LANCASTER, 1987; URBANO, 2000]. However, it was greater than that obtained in other humanities studies. These results are shown in Tables 4 and 5. Several comparisons have been established, because the type of data provided by the authors are not totally homogeneous. Table 5 shows the percentages of references to literature published in the last 5 years (Price Index) and in the last 10 years. Table 6 shows the median (apparent half life) and the arithmetic mean age of the works cited.

The results show that the level of obsolescence is quite high compared with that commonly obtained in other humanities studies, and similar to that obtained in linguistics, a discipline that shows the obsolescence proper to the social sciences [ZWAan, Nederhof, 1990; Nederhof, Noyons 1992; GeOrgas; Cullars 2005]. One interpretation of these apparently atypical results would be that habits in the humanities are changing and the texts cited are increasingly modern, but the average age of the references hardly varied in the 30 years of the study; in fact it increased slightly. We suggest that the relatively high obsolescence values are due to the fact that many of the publications cited appeared only recently after the changes in the political situation in Catalonia in the late 1970s. Though only time will tell whether this is true, Figure 2 compares the results of our study with those of ZAINAB and GOI [1997] and THOMPSON [2002], which offer sufficiently detailed and fairly recent data. Whereas initially the accumulated percentage of references was far greater in our study, for citations older than 30 years the other studies show slightly higher figures. Thus, the references used for Catalan literature are fairly modern, but when there are no current publications, even very old sources are used. In summary, too little work has as yet been published in this discipline.

If we consider obsolescence according to document type, we observe that the highest values are obtained for conference proceedings-calculated from the date of publication - and theses, with Price indexes of 59.4 and 50.0\%, respectively for citations of exclusively Catalan literature. With respect to the conference proceedings, this is normally attributed to their rapid publication and flexibility. In the case of theses, it can be argued that many of them are later published as monographs or articles, which are always more accessible and are therefore cited rather than the original theses. The 
periodical press showed an index of $43.5 \%$, journals $36.9 \%$, book chapters $35.8 \%$, forewords $29.4 \%$ and monographs $28.7 \%$. This order of obsolescence of the different types of document is fully consistent with earlier studies of different disciplines inside and outside the humanities [URBANO 2000; THOMPSON 2002]. We observe that the difference between journals and the different types of documents in book format is not too great. The fact that journals and books are the most cited and have low levels of obsolescence indicates that the immediacy of the research is not currently a critical issue in Catalan literature.

In summary, the general obsolescence of the works cited was fairly low, but that of conference proceedings was considerably higher. Furthermore, more than $5 \%$ of the references were over 50 years old.

\section{Most cited publishers, journals and conferences}

Of the cited documents on Catalan literature published in book format, $78 \%$ were commercial publications (like Wiley and McGraw-Hill), of which 75\% were published in the Catalan-speaking countries, whereas $21 \%$ were published entirely by institutions such as universities, scholarly institutes, governments and local authorities. A total of 130 publishers were identified, with a clear predominance of Edicions 62 (14.9\%) and Publicacions de l'Abadia de Montserrat (12.4\%), publishers that cover many aspects of Catalan culture and are not strictly academic. The cited monographs showed a title dispersion of 570. The first place in the ranking was occupied by Història de la Literatura Catalana by Riquer, Comas and Molas.

The number of journals identified in the citations was 235. Three journals corresponded to a third of the citations, and 20 journals to 65\%. This dispersion is considerably lower than that of other literary studies. For British and American literature, HEINZKILL [1980] found that 20 titles represented 53\% of the citations and THOMPSON [2002] that 20 titles represented 39.2\%. For Spanish language and the literature, URBANO ET AL. [2005] calculated that 20 titles corresponded to $29.5 \%$ of the citations.

The first 11 publications that reached 57\% of the citations (Table 6) can be considered to be the essential core of the discipline for research. They included both those that have a great historical importance, but are losing ground, and those that are achieving an increasing number of citations. Of these 11 publications only Els Marges, Caplletra, Estudis de Llengua i literatura catalanes, Estudis Romànics and Llengua \& literatura are dedicated specifically to philology (not exclusively Catalan), whereas the others include a variety of fields, such as history and philosophy.

In the case of conferences, there was an overwhelming predominance of references to texts of the different editions of the "Col-loqui Internacional de Llengua i Literatura Catalanes", which represented $37.9 \%$ of the total. 


\section{Productivity and collaboration of the authors}

Table 7 shows the distribution of the number of authors according to the number of different works cited, i.e. the number of different authors with a specific number of cited works, including self-citations (2897 different documents). There are few highly cited authors because of the large volume of works cited: $98.81 \%$ of the authors are cited in a very small number of different works ( 1 to 5 ). The highly cited authors are cited for a few highly cited works rather than for a wide body of work that is uniformly cited.

Though the distribution of the number of authors in relation to the number of published contributions follows a power law, it does not follow Lotka's law [LOTKA 1926]. The number of authors making a given number of contributions does not decrease with the square of the number of contributions, but more rapidly, following an approximate expression of $A n=688 / n^{2,151}$, where An represents the number of authors with $n$ different works. However, the results are within the habitual range [NEWBY, GREENBERG, JONES 2003].

The total volume of self-citations in the Catalan literature set cited in this study was 455, representing an $11.1 \%$ share of the total of 4,096 . This is lower than the $19 \%$ share obtained by GLÄNZEL and THIJS [2004] as a world average for 2000 to 2002 in the A\&HCI. This could be influenced by the fact that the percentage of self-citations of a document falls rapidly over time [AKSNES, 2003; GLÄNZEL, THIJS, SCHLEMMER, 2004]. To show the relative importance of excluding self-citations, Table 8 presents examples of authors who used at least $25 \%$ of self-citations. In each case we offer the ranking for all citations and excluding self-citations. As can be seen, though self-citations may not be very significant in terms of national production or in contexts with large volumes of data [AKSNES 2003; GLÄNZEL, THIJS 2004], they can have a considerable effect on the results when the number of records is necessarily small.

As was foreseeable, the degree of collaboration studied by means of the co-authorship index was very low. Documents with a single author represented $96.7 \%$ of the references, so co-authorship was reduced to 3.3\%, with an average of 1.04 authors per document. These values are similar to, but even lower than, those found by previous authors dealing with the humanities (Argentine authors in the A\&HCI 5.9\%, Turkish authors 17\%, history 7\%). [Molteni, ZuluetA, 2002; Lowe 2003; Al, SAHINER, TONTA 2006]. It seems fairly obvious that Catalan literature follows the habitual parameters in these disciplines insomuch that authors work individually with specific aspects of research rather than collaborating with others.

Mapping of the discipline and its trends: cited literary periods, authors and works, and co-citation cluster analysis

The study of Catalan literature and its history tends to be divided into four main areas [MOLAS, 2001; DURAN, 2004]: literary theory and comparative literature; mediaeval literature (up to the 15th century); modern literature (16th, 17th and 18th centuries and 
first third of the 19th century); and contemporary literature (from the second third of the 19th century to the present). Our study shows a major predominance of studies of contemporary literature-almost two thirds of the total (Table 9). We also added a category that includes general documents on history of literature that deal with all periods and aspects. Despite the predominance of citations on contemporary literature, the specific literary work most dealt with by the articles cited was Tirant lo Blanc, a work dating from 1490, at $37 \%$ of the total of works dealing with a specific literary work. Correspondingly, the literary figure most studied was its author, Joanot Martorell. Co-citation analysis can be used to show affinities between authors [SMALL, SWEENEY 1985; Small, Sweeney, Greenlee 1985; Kreuzman 2001]. In our case we show the results obtained with the authors cited 15 or more times by means of the non-metric multidimensional scaling technique (MDS). This technique shows the objects in a twodimensional metric space. Each object in the metric space is represented by two coordinates and the distance between two objects is calculated by a Euclidian norm based on the order of position of each one. The calculation consists in minimising by iterations an error function that evaluates, for all the vertex pairs, the difference between the similarity index and the distance in the two-dimensional metric space. When the coordinates are obtained, they are represented by a graphic figure similar to a map. In MDS techniques the axes of the figure obtained have no special significance because the only thing that is important is the relative position between them. In our work the stress has a value of approximately 0.19, which is considered acceptable [BORGATTI, EVERETT, FREEMAN 2002].

The first classification groups the authors according to the main subarea of study for which they are cited (Figure 3). The authors on the right of the figure are cited for their works on contemporary literature, those on the left for mediaeval literature and those in the centre for modern literature.

However, other possible associations are also observed. On the centre right of Figure 3 there is a group of authors cited jointly on several occasions for their studies on literature of the Valencian Community. Further to the right of the figure are authors cited for their theatrical studies (Figure 4). In the lower part of Figure 3 there is a group of authors cited for their studies on the Balearic Islands (figure 5). Finally, we distinguished a subgroup of authors who are cited for their studies on Menorcan literature.

Figure 6 shows the network that is formed by the relations between the most cited authors when they are co-cited. The relations between the elements of this symmetric graph are formed by a statistically significant covariance of 0.6. The representation algorithm used was that proposed by KAMADA and KAWAI [1989]. The network is formed by 4 components. The principal component includes scholars of contemporary literature, and has a subcomponent situated at the top left, formed by the authors who are theatre scholars. At the bottom left there is a component that includes scholars of literature of the Balearic Islands. At the bottom right, there is a small component that 
includes scholars of Menorcan literature. Finally, just above this is the component of scholars of mediaeval and modern literature. It should be noted that the authors cited for their studies on literature of the Valencian Community, on the centre left, are strongly linked to the other scholars of contemporary literature, so unlike theatre scholars they are not distinguished as a substructure.

Figures 4-6 show a disperson that we could easily attribute to the tendency towards specialisation of the academic world, but it could also be due to the relative newness of this branch of philology. In this case, the charts show a certain isolation of groups, schools and subjects, which would indicate a certain structural weakness. The historical circumstances force scholars to cover the many gaps in each area (complete bibliographies of each author and each period, critical editions of texts, etc.) before undertaking research that takes into account works of the whole linguistic area, or movements that go beyond the sphere (geographic, temporal, thematic, etc.) in which they are working.

\section{Conclusions}

In this study we have analysed the citations obtained by ad hoc extraction from journals on Catalan literature in the absence of journals indexed in the A\&HCI. The lack of data makes it difficult to perform studies of this type as often as is habitual in sciences or social sciences. However, the present article shows that the greater effort required in gathering data is compensated by a large set of indicators on research in the discipline without the need to consult the specialists involved. Based on the citation analysis, we have drawn the following conclusions, which place this discipline for the first time on the world map of bibliometric studies, with many similarities and a few differences:

The consumption of bibliographic information by researchers into Catalan literature has the same general characteristics as in other humanities disciplines. It has a low level of obsolescence, with a half life of 11 years for all the citations, which shows once more that immediacy is not an important factor in humanities.

Catalan was the language of both the citing and cited texts in two thirds of the cases, relegating English to second place. Furthermore, a third of the citations were not specifically to texts on Catalan literature, but to texts on complementary disciplines, an essential characteristic of the humanities in which a high degree of interdisciplinarity is assumed.

Co-authorship was found in less than $4 \%$ of the documents cited. Therefore, it can also be concluded that Catalan literature follows the tendency habitual in the humanities by which authors tend to work individually on specific aspects of research rather than to work together. This is an indicator that should be monitored if it is desired to make work in the humanities more open and collaborative.

All mature areas of science have suitable means of publication. One of the characteristics of maturity is having a core of specialised journals. In the area of Catalan 
literature this core is blurred by the presence of several publications not devoted to philology among the most cited, in addition to a smaller degree of dispersion than is habitual in literature. There is only a token presence of citations of international journals of Romance studies or philology. Everything suggests that there is certain lack of consolidation of the media, and of scientific validation. This view is supported by the figures on the age of the works cited. However, these results must be compared with those of studies that have a far more exhaustive number of citations and with others on literatures in minority languages that have a different social and political background to Catalan.

The proportion of self-citations by authors was $11.1 \%$, but we do not know the extent to which this may be influenced by the small size of the research community. The comparison with literatures of other European languages, both culturally dominant and minority, could show whether this aspect is relevant or is fairly standard.

One of the particularities of bibliometric research is that it provides quantitative data that go beyond mere impressions without the need to consult specialists. In our study, we can conclude that the area that accumulates most research in Catalan literature is the contemporary period. We can also state that the literary work that is the subject of the most cited works is Tirant lo Blanc (1490) by Joanot Martorell, which tells us what is most important for researchers, without subjective bias.

The thematic analysis and the co-citation analysis show the presence of clusters of researchers with a clear regional orientation towards the Valencian Community and the Balearic Islands - a phenomenon that is not rare in the humanities. It remains to be seen whether the co-citation analysis of the works cited can provide similar information to the thematic analyses of journals based on an ad hoc human classification that have been carried out by several authors. 


\section{References}

AKSNES, D. W. (2003), A macro study of self-citation, Scientometrics, 56: 235-246.

AL, U., SAHINER, M., TONTA, Y. (2006), Arts and Humanities Literature: bibliometric bharacteristics of bontributions by Turkish authors, Journal of the American Society for Information Science and Technology, 57: 1011-1022.

ARDANUY, J. (2008), Anàlisi bibliomètrica de la producció científica en literatura catalana, Universitat de Barcelona, Barcelona. Available online at: <www.tesisenxarxa.net/TDX0226108-124023/index.html>, accessed on 20 May 2008.

Borgatti, S. P.; EveretT, M. G.; FrEEMAN, L. C. (2002). Ucinet for Windows: Software for Social Network Analysis, Analytic Technologies, Harvard.

BUDD, J. (1986), Characteristics of written scholarship in American literature: A citation study, Library and Information Science Research, 8: 189-211.

CULlaRs, J. (1985), Characteristics of the monographic literature of British and American literary studies, College and Research Libraries, 46: 511-522.

Cullars, J. (1988), Characteristics of the Monographic Scholarship of Foreign Literary Studies by Native Speakers of English, College and Research Libraries, 49: 157-170.

Cullars J. (1989), Citation Characteristics of French and German Literary Monographs, Library Quarterly, 59: 305-325.

CULlARS, J. (1990), Citation characteristics of Italian and Spanish literary monographs, Library Quarterly, 60: 337-356.

Cullars, J. (1992), Citation characteristics of monographs in the fine arts, Library Quarterly, 62: 325-342.

CUllaRs, J. (1996), Citation characteristics of French and German fine arts monographs, Library Quarterly, 66: 138-160.

CULLARS, J. (1998), Citation characteristics of English language monographs in philosophy, Library and Information Science Research, 20: 41-68.

DURAN, E. (coord.) (2004), Reports de la recerca a Catalunya. 1996 - 2002 filologia catalana: literatura, Institut d'Estudis Catalans, Barcelona. Available online at: $<$ www2.iecat.net/gc/digitalAssets/3701_1097665504296_litcat9602.pdf>, accessed on 20 May 2008.

ELLIS, D., OLDMAN, H. (2005), The English literature researcher in the age of the Internet, Journal of Information Science, 31: 29-36.

FERnÁndeZ-IzQuierdo, F., Román, A., Rubio-Liniers, M. C., Moreno, F. J., MARTínMoreno, C., García-Zorita, J. C.; Lascurain M. L., García, P. E., Povedano, E., SANZ, E. (2007), Bibliometric study of early Modern History in Spain based on bibliographic references in national scientific journals and conference proceedings. In: D. Torres-Salinas, H. F. Moed (Eds), 11 International Conference of the International Society for Scientometrics and Informetrics. CSIC, Madrid, vol. 1, pp. 266-271.

GARFIELD, E. (1980), Is information retrieval in the arts and humanities inherently different from that in science? The effect that ISI's citation index for the arts and humanities is expected to have on future scholarship, Library Quarterly, 50: 40-57.

GeORGas, H.; Cullars, J. (2005), A citation study of the characteristics of the linguistics literature, College and Research Libraries, 66: 496-515.

GLÄNZEL, W., THIJS, B. (2004), The influence of author self-citationson bibliometric macro indicators, Scientometrics, 59: 281-310.

GLÄNZEL, W., ThIJS, B., SCHLEMMER, B. (2004), A bibliometric approach to the role of author self-citationsin scientific communication, Scientometrics, 59: 63-77.

GLEAVES, E. S. (1961), Characteristics of the research materials used by scholars who write in journals in the field of American literature., ACRL Microcard, 130, University of Rochester Press, Rochester.

HEINZKILL, R. (1980), Characteristics of references in selected scholarly English literary journals, Library Quarterly, 50: 352-365.

HERUBEL, J. P., BuChANAN, A. L. (1994), Characteristics of references in selected scholarly English journals, Collection Management, 18: 89-137. 
JonEs, C., ChAPMAN, M., WoOds, P. C. (1972), The characteristics of the literature used by historians, Journal of Librarianship, 4: 137-156.

KAMADA, T., KAWAI, S. (1989), An algorithm for drawing general undirected graphs, Information Processing Letters, 31: 7-15.

KREUZMAN, H. (2001), A co-citation analysis of representative authors in philosophy: Examining the relationship between epistemologists and philosophers of science,. Scientometrics, 51: 525-539.

LINDHOLM-ROMANTSCHUK, Y., WARNER, J. (1996), The role of monographs in scholarly communication: An empirical study of philosophy, sociology and economics, Journal of Documentation, 52 (4): 389-404.

LOTKA, A J. (1926), The frequency distribution of scientific productivity, Journal of the Washington Academy of Sciences, 16: 317-323.

LOWE, M. S. (2003), Reference analysis of the 'American Historical Review', Collection Building, 22: 13-20.

MCCAIN, K. W. (1987), Citation patterns in the history of tecnology, Library and Information Science Research, 9: 41-59.

MolAS, J. (coord.) (2001), Reports de la Recerca a Catalunya. Literatura catalana, Institut d'Estudis Catalans, Barcelona. Available online at: $<$ www2.iecat.net/gc/digitalAssets/3686_1097661647515_literatura.pdf>, accessed on 20 May 2008.

Molteni, V.; ZuluetA, M. A. (2002), Análisis de la visibilidad internacional de la producción científica argentina en las Bases de datos Social Science Citation Index y Arts and Humanities Citation Index de 1990-2000, Revista Española de Documentacion Cientifica, 25: 455-465.

NEDERHOF, A, J. (2006), Bibliometric monitoring of research performance in the Social Sciences and the Humanities: a review, Scientometrics, 66: 81-100.

NEDERHOF, A. J., ERLINGS, C. M. (1993), A bibliometric study of productivity and impact of modern language and literature research in The Netherlands, 1982-1991, Center for Science and Technology Studies (CWTS), Leiden.

NEDERHOF, A. J.; NOYONS, E. C. M. (1992), International comparison of departments' research performance in the humanities, Journal of the American Society for Information Science and Technology, 43: 249-256.

NEDERHOF, A. J., ZWAAN, R. A, BRUin, P. J. DE, DEKKER, P. J. (1989), Assessing the usefulness of bibliometric indicators for the humanities and the social and behavioural sciences: a comparative study, Scientometrics, 15: 423-435.

NewBy, G. B., GreenBerG, J., JoneS, P. (2003), Open Source Software Development and Lotka's Law: Bibliometric Patterns in Programming. Journal of the American Society for Information Science and Technology, 54: 169-178.

PRICE, D. J. D. (1970), Citation measures of hard science, soft science, Technology and nonscience. In: C. E. NELSON, D. K. POLLOCK (Eds), Communication among scientists and engineers. Heat, Lexington.

SHAW, W. (2002), The use of the Internet by academics in the discipline of English literature: a quantitative and qualitative approach, University of Wales, Aberystwyth.

SMALL, H., SWEENEY, E. (1985), Clustering the science citation index using co-citations I: a comparison of methods, Scientometrics, 7: 391-409.

SMALl, H., SWEenEy, E., GREENLEE, E. (1985). Clustering the science citation index using co-citations II: mapping science. Scientometrics, 8: 321-340.

STERN, M. (1983), Characteristics of the literature of literary scholarship, College and Research Libraries, 44: 199-209.

STINSON, E. R., LANCASTER, F. W. (1987), Synchronous versus diachronous methods in the measurement of obsolescence by citation studies, Journal of Information Science, 13: 65-74. STONE, SuE (1982), "Progress in documentation. Humanities scholars: Information needs and uses", Journal of Documentation, 38: 292-313.

Thompson, J. W. (2002), The Death of the Scholarly Monograph in the Humanities? Citation Patterns in Literay Scholarship, Libri 52: 121-136. 
Urbano, C. (2000), El análisis de citas en publicaciones de usuarios de bibliotecas universitarias: estudio de tesis doctorales en infomática de la Universidad Politécnica de Cataluña, 1996-1998, Universitat de Barcelona, Barcelona. Available online at: <www.tesisenxarxa.net/TDX-0614102-113014/index.html>, accessed on 20 May 2008.

Urbano, C., Borrego A., Brucart, J. M., Cosculluela, A.; Somoza, M. (2005), Análisis bibliométrico de la bibliografía citada en estudios de filología espanyola, Revista Española de Documentacion Cientifica, 28: 439-461.

Urbano, C., Borrego, A., Rodríguez-Gairín, J. M., Ardanuy, J., Brucart, J. M., Cosculluela, A., Guardiola, E., Pons, A., Somoza, M. (2004), la evaluación de revistas en procesos de evaluación de la investigación española en humanidades y ciencias sociales: desarrollo de un modelo y experimentación en el área de filología hispánica. Informe EA2004-00025 del Programa de Estudios y Análisis del MEC, Ministerio de Educación i Ciencia, Madrid. Available online at: <www.mec.es/univ/html/informes/estudios_analisis/resultados_2004/ea0025/ea0025.pdf>, accessed on 20 May 2008.

WATSON-BOONE, R. (1994), Information needs and habits of humanities scholars, Reference Quarterly, 34: 203-216.

ZAINAB, A. N., GOI, S. S. (1997), Characteristics of citations used by humanities researchers, Malaysia Journal of Library \& Information Science, 2: 19-36.

ZWAAN, R. A; NEDERHOF, A. J. (1990), Some aspects of scholarly communication in linguistics: An empirical study, Language, 66: 523-527. 
Figure 1. Chronological distribution of the documents cited according to date of publication

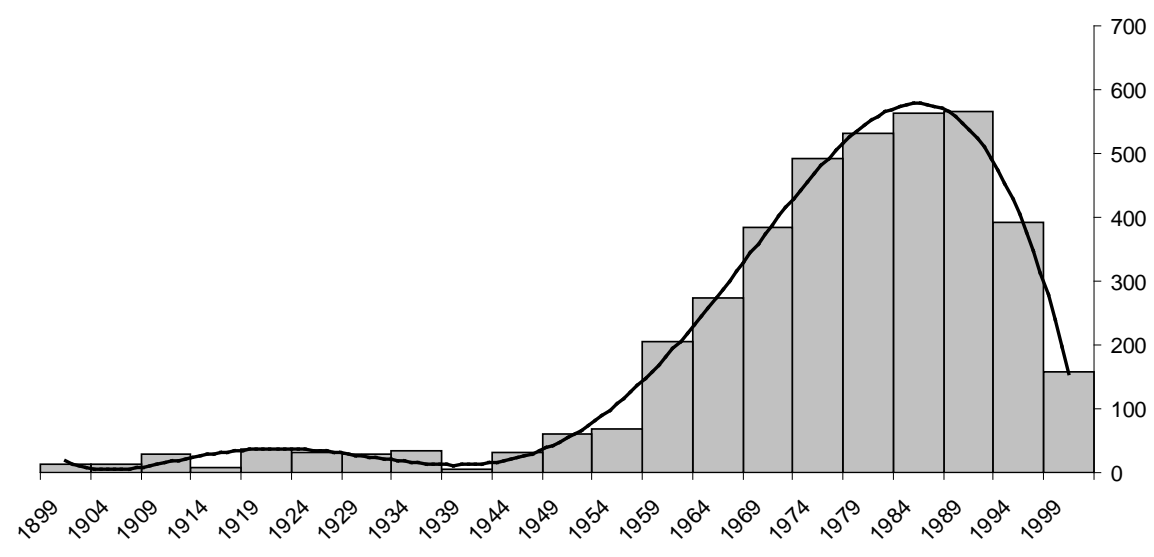

Figure 2. Accumulated percentage of citations according to age

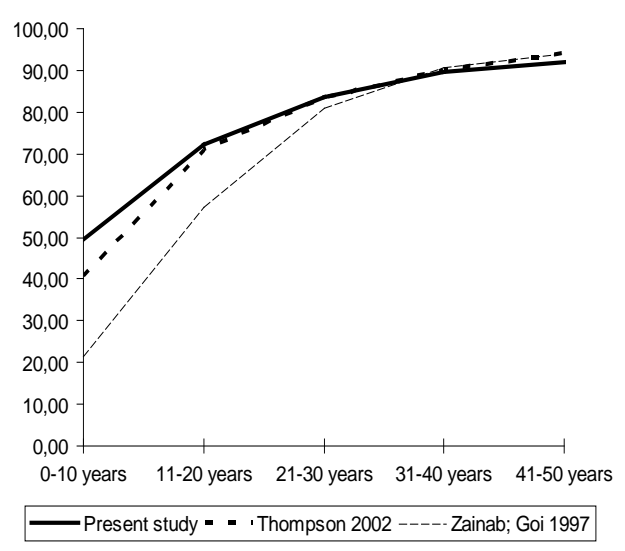

Figure 3. Grouping of authors according to the period of literature for which they are mainly cited

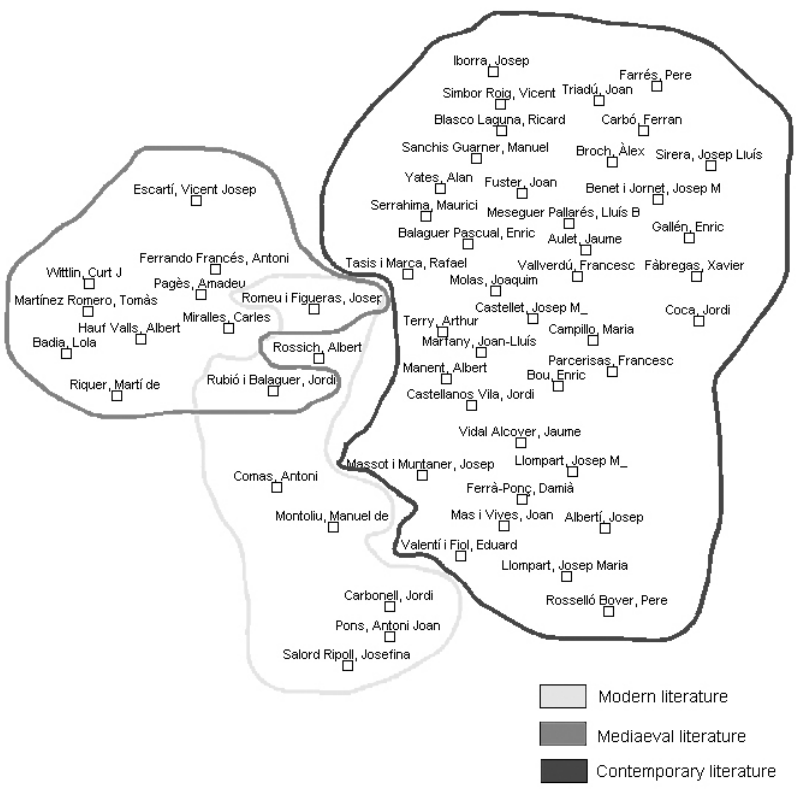


Figure 4. Grouping of authors co-cited for their theatrical studies and their studies on the literature of the Valencian Community

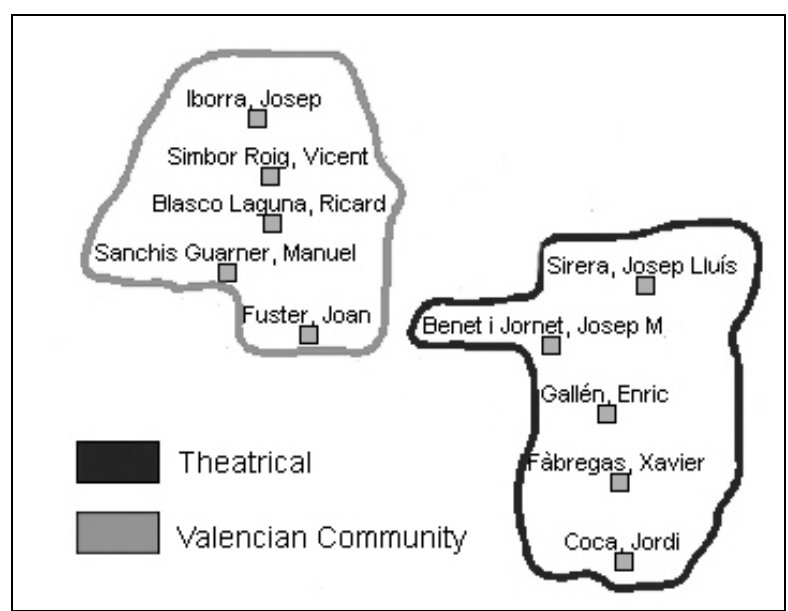

Figure 5. Grouping of authors co-cited for their studies on the Balearic Islands in general and Menorca in particular

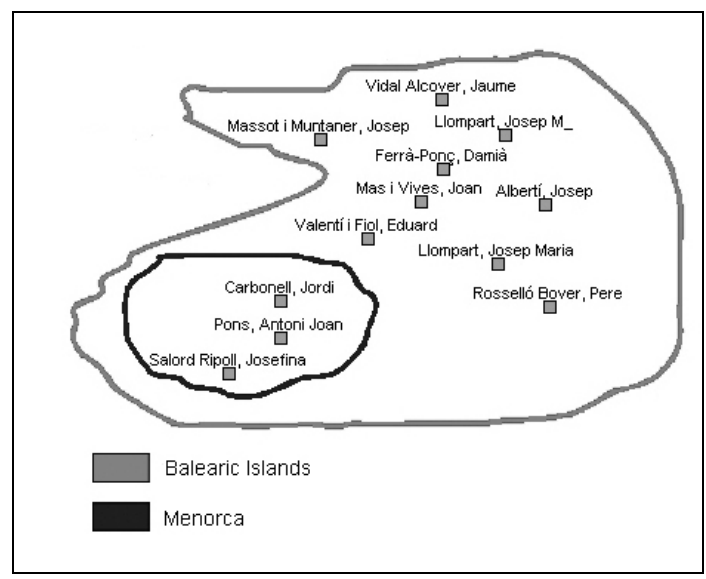


Figure 6. Network of co-citation

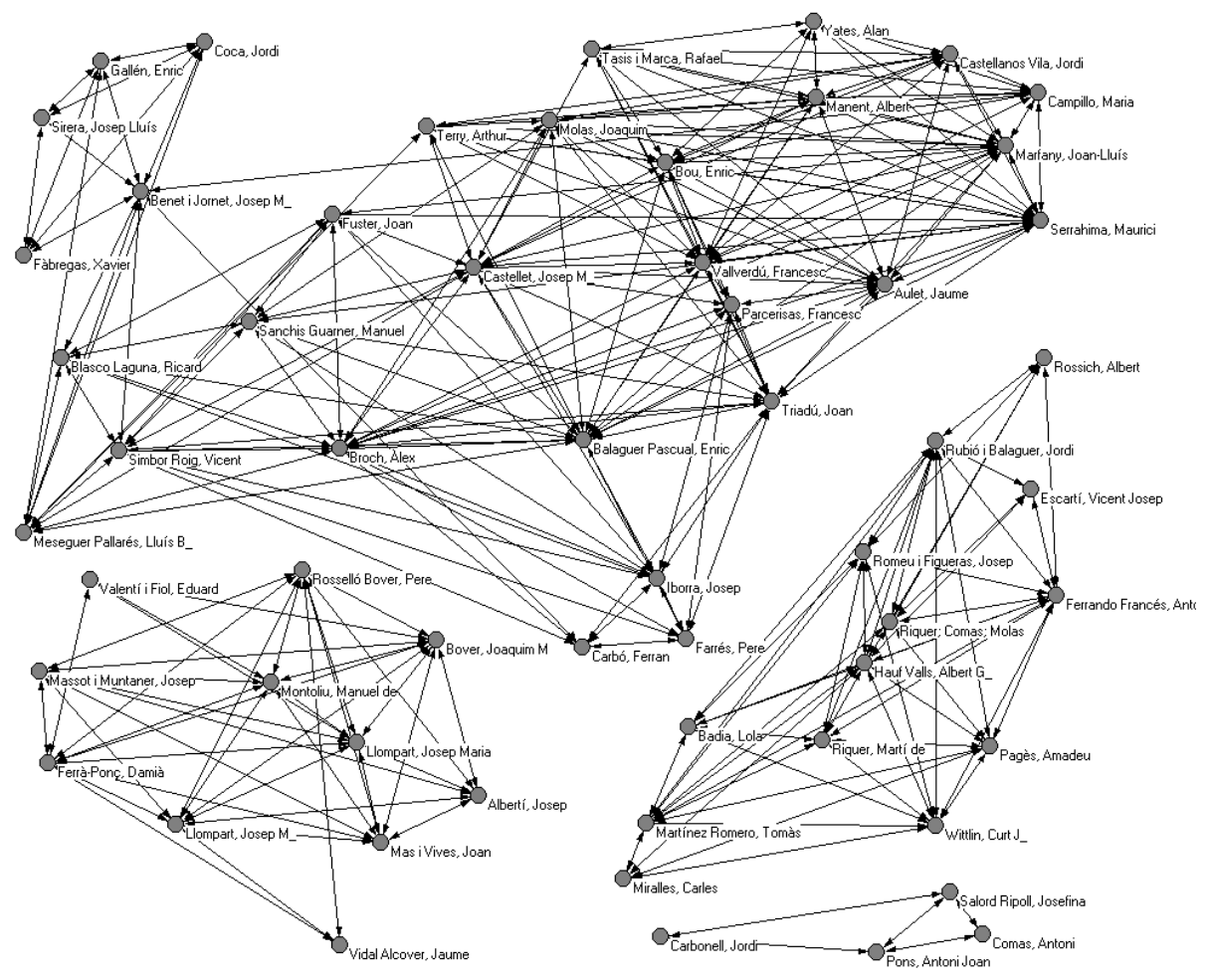


Table 1. Distribution of references dealing with different literatures

\begin{tabular}{|l|c|}
\hline Literature & $\begin{array}{c}\text { \% of } \\
\text { references }\end{array}$ \\
\hline Spanish & 39.9 \\
\hline French & 12.6 \\
\hline Mediaeval European & 8.1 \\
\hline Humanistic ${ }^{*}$ & 7.8 \\
\hline Classical & 7.5 \\
\hline Italian & 6.7 \\
\hline English & 5.9 \\
\hline Occitan & 3.6 \\
\hline German & 2.0 \\
\hline Universal & 2.0 \\
\hline Galician and Portuguese & 1.1 \\
\hline Modern and contemporary European & 0.8 \\
\hline Slavic & 0.8 \\
\hline North American & 0.6 \\
\hline Arabic & 0.3 \\
\hline Hebrew & 0.3 \\
\hline${ }^{*}$ Literature written in Latin in Europe after its \\
disappearance as a language of daily use. \\
\hline
\end{tabular}

Table 2. Distribution of references according to groups of document types

\begin{tabular}{|l|c|c|c|c|}
\hline \multirow{2}{*}{ Document types } & \multicolumn{2}{c|}{$\begin{array}{c}\text { Documents of Catalan } \\
\text { literature cited }\end{array}$} & \multicolumn{2}{c|}{ Total documents cited } \\
\cline { 2 - 5 } & $\begin{array}{c}\text { No. of } \\
\text { documents }\end{array}$ & $\begin{array}{c}\text { \% of } \\
\text { documents }\end{array}$ & $\begin{array}{c}\text { No. of } \\
\text { documents }\end{array}$ & $\begin{array}{c}\text { \% of } \\
\text { documents }\end{array}$ \\
\hline Book format (monographs, etc.) & 2,288 & 55.86 & 3,827 & 62.65 \\
\hline Journals & 1,328 & 32.42 & 1,709 & 27.98 \\
\hline Conference proceedings & 198 & 4.83 & 252 & 4.13 \\
\hline Magazines and newspapers & 194 & 4.74 & 217 & 3.55 \\
\hline Theses and research projects & 78 & 1.90 & 90 & 1.47 \\
\hline Others & 10 & 0.24 & 14 & 0.22 \\
\hline Total & 4,096 & 100 & 6,109 & 100 \\
\hline
\end{tabular}


Table 3. Percentages of monographs and serial publications in philology studies

\begin{tabular}{|l|l|c|c|}
\hline \multicolumn{1}{|c|}{ Source } & \multicolumn{1}{c|}{ Area of study } & $\begin{array}{c}\text { \% of } \\
\text { monographs }\end{array}$ & $\begin{array}{c}\text { \% } \\
\text { Series }\end{array}$ \\
\hline [Cullars, 1988] & Non-English literatures studied by English-speakers & 81.0 & 10.9 \\
\hline [Cullars, 1985] & UK and US literature in English & 65.7 & 13.3 \\
\hline [Stern, 1983] & Literature: writers & 82.7 & 15.1 \\
\hline [Cullars, 1990] & Spanish literature & 75.5 & 15.9 \\
\hline [Stern, 1983] & Literature: literary movements & 78.8 & 16.5 \\
\hline [Thompson, 2002] & 19th-century British and American literature in & 66.9 & 18.0 \\
\hline EHeinzkill, 1980] & British literature in English & 75.0 & 19.9 \\
\hline [Cullars, 1989] & German literature & 70.5 & 22.5 \\
\hline [Cullars, 1990] & Italian literature & 71.5 & 22.6 \\
\hline [Budd, 1986] & US literature in English & 64.0 & 23.0 \\
\hline$[$ Cullars, 1989] & French literature & 70.1 & 27.6 \\
\hline$[$ Gleaves, 1961] & North American literature in English & $?$ & 34.7 \\
\hline
\end{tabular}


Table 4. Price index of the documents cited in several studies of humanities

\begin{tabular}{|c|c|c|c|}
\hline Source & Area of study & $\begin{array}{c}\text { Price index, \% } \\
\text { five years or less }\end{array}$ & $\begin{array}{c}\text { \% } 10 \text { years } \\
\text { or less }\end{array}$ \\
\hline [CULLARS 1985] & UK and US literature in English & $0.0 *$ & - \\
\hline [CULLARS 1990] & Italian literature & - & 6.7 \\
\hline [CULLARS 1989] & French literature & $3.9 *$ & - \\
\hline [CULLARS 1996] & Fine Arts (French monographs) & - & 11.9 \\
\hline [CULLARS 1990] & Spanish literature & - & 13.0 \\
\hline [CULLARS 1989] & German literature & $8.3 *$ & - \\
\hline [CULLARS 1998] & Philosophy & $8.9 *$ & - \\
\hline [CULLARS 1992] & Fine arts & 10.8 & - \\
\hline [PRICE 1970] & General philosophy & 12 & - \\
\hline [BUDD 1986] & US literature in English & 14.0 & 29.4 \\
\hline [MCCAIN 1987] & History of technology & 15.0 & 36.0 \\
\hline [THOMPSON 2002] & British and American literature in English & 16.6 & 26.1 \\
\hline [CULLARS 1996] & Fine Arts (French monographs) & - & 15.6 \\
\hline [PRICE 1970] & Philosophy (Philosophy of Science) & 21 & - \\
\hline [PRICE 1970] & Philosophy (Journal of Symbolic Logic) & 22 & - \\
\hline [ZAINAB; GOI 1997] & $\begin{array}{l}\text { Religion, philosophy, history and } \\
\text { philology }\end{array}$ & - & 21.5 \\
\hline [HEINZKILL 1980] & British literature in English & - & - \\
\hline [LOWE 2003] & History & - & $35.0 *$ \\
\hline [AL; SAHINER; TONTA 2006] & Humanities (Turkey) & 24 & - \\
\hline [GARFIELD 1980] & Humanities & - & $38.0 *$ \\
\hline [WEINTRAUB 1980] & Humanities & - & $40 *$ \\
\hline PRESENT STUDY & All references & 31.5 & 49.6 \\
\hline [GEORGAS; CULLARS 2005] & Linguistics & - & $53.6 * *$ \\
\hline Present study & References of Catalan literature & 35.1 & 53.7 \\
\hline [ZWAAN; NEDERHOF 1990] & Linguistics & - & 61 \\
\hline $\begin{array}{l}* \text { One year less is counted } \\
* * \text { One year more is count }\end{array}$ & & & \\
\hline
\end{tabular}

Table 5. Apparent and arithmetic half life of the citations in several studies of humanities

\begin{tabular}{|l|l|c|c|}
\hline \multicolumn{1}{|c|}{ Source } & \multicolumn{1}{|c|}{ Area of study } & \multicolumn{1}{c|}{$\begin{array}{c}\text { Average } \\
\text { age }\end{array}$} \\
\hline Present study & References of Catalan literature & 9 & 16.2 \\
\hline Present study & All references & 11 & 18.7 \\
\hline [URBANO ET AL. 2005] & Books on Spanish philology & 12 & 17.7 \\
\hline [URBANO ET AL. 2005] & Journals on Spanish philology & 12 & 18.8 \\
\hline [THOMPSON 2002] & British and American literature in English & 13 & - \\
\hline [FERNÁNDEZ-IZQUIERDO et al. 2007] & Modern history (Spanish journals) & 19 & 17.0 \\
\hline [JONES; CHAPMAN; WOODS 1972] & Mediaeval English history & 39 & - \\
\hline [JONES; CHAPMAN; WoODS 1972] & Modern English history & 54 & - \\
\hline [JONES; CHAPMAN; WOODS 1972] & Contemporary English history up to 1914 & 71 & - \\
\hline
\end{tabular}


Table 6: Most important journals in number of citations received

\begin{tabular}{|l|c|c|c|}
\hline Title & $\begin{array}{c}\text { No. of } \\
\text { citations } \\
\text { per title }\end{array}$ & $\begin{array}{c}\text { Accumulate } \\
\text { d no. of } \\
\text { references }\end{array}$ & $\begin{array}{c}\text { Accumul } \\
\text { ated \% of } \\
\text { reference } \\
\text { s }\end{array}$ \\
\hline Serra d'Or & 252 & 252 & 19.3 \\
\hline Els Marges & 112 & 364 & 27.8 \\
\hline Randa & 92 & 456 & 34.8 \\
\hline Caplletra & 50 & 506 & 38.7 \\
\hline ELLC & 46 & 552 & 42.2 \\
\hline Revista de Catalunya & 39 & 591 & 45.1 \\
\hline BRABLB & 36 & 627 & 47.9 \\
\hline Lluc & 35 & 662 & 50.6 \\
\hline Estudis Romànics & 34 & 696 & 53.2 \\
\hline Revista de Menorca & 30 & 726 & 55.5 \\
\hline Llengua \& literatura & 20 & 746 & 57.0 \\
\hline
\end{tabular}

Table 7. Number of different works cited for each author cited.

\begin{tabular}{|c|c|c|c|}
\hline Works cited & $\begin{array}{c}\# \\
\text { authors }\end{array}$ & $\begin{array}{c}\text { \% of } \\
\text { authors }\end{array}$ & $\begin{array}{c}\text { Accumulated \% } \\
\text { of authors }\end{array}$ \\
\hline 80 & 1 & 0.10 & 0.10 \\
\hline 59 & 1 & 0.10 & 0.19 \\
\hline 41 & 1 & 0.10 & 0.29 \\
\hline 39 & 1 & 0.10 & 0.39 \\
\hline 35 & 2 & 0.19 & 0.58 \\
\hline 32 & 2 & 0.19 & 0.77 \\
\hline 31 & 1 & 0.10 & 0.87 \\
\hline 25 & 1 & 0.10 & 0.97 \\
\hline 24 & 1 & 0.10 & 1.06 \\
\hline 23 & 1 & 0.10 & 1.16 \\
\hline 22 & 2 & 0.19 & 1.35 \\
\hline 20 & 3 & 0.29 & 1.64 \\
\hline 19 & 1 & 0.10 & 1.74 \\
\hline 18 & 1 & 0.10 & 1.84 \\
\hline 17 & 2 & 0.19 & 2.03 \\
\hline 16 & 1 & 0.10 & 2.13 \\
\hline 11 to 15 & 21 & 2.03 & 4.16 \\
\hline 6 to 10 & 52 & 5.03 & 9.19 \\
\hline 1 to 5 & 939 & 90.81 & 100 \\
\hline
\end{tabular}


Table 8. Relative position of some authors including and excluding self-citations

\begin{tabular}{|c|c|c|c|c|}
\hline $\begin{array}{c}\text { Place in the } \\
\text { ranking } \\
\text { including self- } \\
\text { citations }\end{array}$ & $\begin{array}{c}\text { Place in the } \\
\text { ranking } \\
\text { excluding } \\
\text { self-citations }\end{array}$ & $\begin{array}{c}\text { Total no. } \\
\text { of } \\
\text { citations }\end{array}$ & $\begin{array}{c}\text { No. of } \\
\text { citations } \\
\text { excluding } \\
\text { self-citations }\end{array}$ & $\begin{array}{c}\text { \% of self- } \\
\text { citations to } \\
\text { the total }\end{array}$ \\
\hline 4 & 5 & 87 & 62 & 28.7 \\
\hline 9 & 241 & 54 & 3 & 94.4 \\
\hline 23 & 37 & 27 & 16 & 40.7 \\
\hline 28 & 58 & 25 & 13 & 52.0 \\
\hline 32 & 47 & 21 & 13 & 38.1 \\
\hline 38 & 61 & 18 & 11 & 38.9 \\
\hline 43 & 61 & 17 & 11 & 35.3 \\
\hline 43 & 82 & 17 & 9 & 47.1 \\
\hline 43 & 82 & 17 & 9 & 47.1 \\
\hline
\end{tabular}

Table 9. Percentage of citations according to areas and historical periods of Catalan literature

\begin{tabular}{|l|c|}
\hline \multicolumn{1}{|c|}{ Areas and historical periods } & \% of citations \\
\hline Contemporary literature & $65 \%$ \\
\hline Modern literature & $8 \%$ \\
\hline Mediaeval literature & $21 \%$ \\
\hline History of all periods & $3 \%$ \\
\hline Literary theory and comparative literature & $3 \%$ \\
\hline
\end{tabular}

